\title{
On Modernism's Secret Anxieties
}

\author{
Gerrit Confurius \\ translated by A.-Chr. Engels-Schwarzpaul
}

The moderns looked upon strong and enveloping, closed forms with suspicion. These forms have been ideologically suspect ever since - even though we usually respond positively to them and, on holidays, even seek them out in traditional cities. The modern avant-garde was obsessively occupied with opening, perforating and de-materialising walls. Meanwhile, a fashion for neo-Romantic, literary nightmares centred on anxious atmospheres in excessively closed rooms. Openness, though, causes us no less discomfort.

A lapse in the ability to locate and recognise space (when one no longer knows what to expect to happen in rooms) and the lack of boundaries between different spheres of action are experienced as a loss of security and personal identity. The mere fact that a room is accessible to anyone at will can cause feelings of subjection, since one can only develop coherent expectations if spaces are adequately differentiated according to their use. Thus, the troubled relationship between spaces and actions, already evident in Flaubert's Madame Bovary (the declaration of love at the agricultural show, for instance), turns into complete dissonance with Kafka. Spaces switch purpose arbitrarily. The court sits in the attic, the neighbour Fräulein Bürstner's room is used for negotiations.

The case against Joseph $\mathrm{K}$. is heard in an everyday world, in backyards or waiting rooms, always in different and unexpected places which the accused does not so much enter as find himself in by mistake. One day, for instance, he finds himself in an attic. The galleries are packed full of people who have crowded in to follow the proceedings. They have come expecting a lengthy session, but conditions up there are almost unbearable. The ceiling (ceilings are almost always low in Kafka) presses down on them ..." (Benjamin 2005: 495-6, translation modified).

We still feel Kafka's unease in the face of the dislocation of sense from space, perhaps even more so today. By contrast, the discomfort caused by rigidly defined, overly mapped-out and enclosed space appears strangely stale and dated to us. This tight link-up of space and action, which seems to render free will a chimera (as we sense it in Fritz Lang's films where, without exception, people are caught up in ineluctable situations), no longer strikes a chord with us.

2

Whence did the avant garde derive their certainty about the course they set for the future? Recalling post-war discussions about Germany's denazification, one has to ask how anyone at that time could confidently determined how architecture could have best contribute to democracy. With a conviction that today seems grotesque, Le Corbusier and Scharoun's designs were associated with an un-neurotic liberality. Their designs were thought to address the preconditions necessary for a fostering of democracy - something that was to be further stabilised through the establishment of town planning. 
Considering the formal properties which were to characterise the ethical and political tasks of town-planning and architecture - Zeilenbau (open rows of housing), orientation, light and air, formal restraint, exorcism of ornament; meandering footpaths and streets; and the strict separation of car and pedestrian traffic, dwelling and working - one realises that all these principles were later abandoned, for good reasons, in favour of a return to, for instance, perimeter block development and increased urban density. As ideological principles, zoning and the separation of functions determined all formal characteristics of modernism. In a critical light though, the dogma of the differentiation of zones with mono-cultural use becomes recognisable as a nervous and neurotic response to an excess of openness - indeed, as a conservative reaction to a Kafkaesque surplus of openness.

Le Corbusier gives himself away in his writings. In his own words, he hates the theatrical throng of the old city. The inhabitants of his Radiant City were to be spared the sight of so many people, so many faces and desires. Through the glass wall of a luxurious monastic cell, they were to enjoy, in "tranquillity, solitude and light" (1923), a landscape composed into the city. Latent anxiety shines through his optimistic vision of the future when he observed that everything in the cities of his time was confused, everything being piled on top of each other and mixedup - and thereby compromised. These urban mixtures, caused by a rampant lack of planning, turned into a chaos that needed urgently to be opposed with order.

For Le Corbusier, the therapeutic prescription was a "will for organisation" copied from industry. The efficiency of the city had to be improved.

The city will take on the character of an enterprise that has been carefully studied in advance and subjected to the rigor of an overall plan. Intelligent forecasts will have sketched its future ... And the increase in its population figures will no longer lead to that inhuman melée that is one of the afflictions of the big cities. (Le Corbusier 1942) ${ }^{1}$

"The cycle of daily functions" (1942) in the urban areas was to be allowed to occur separately, as a chain of operations, as it could be admired in the modern factories of North America.

3

This segregation, modelled on factory organisation, served as the epitome of a healing order. Le Corbusier on the Ville Radieuse: "In the Ford factory, everything is collaboration, unity of views, unity of purpose, a perfect convergence of the totality of gestures and ideas.” (Quoted in Ford, 2003: 13) Le Corbusier adapts the ostensible motif for increased efficiency through Fordization - by which industrialists like Michelin, Thoman Bat'a or Henry Ford had declared war on waste and loss of time in their workforce - in order to do battle against frictional losses in the Radiant City, where (not missing a single chance) a diabolical tyranny of disorder is unceasingly at work. The slightest opportunity will suffice - for instance an unsuccessful arrangement of building and access ways, which serve no other purpose than providing a pretext for idle walks or the unnecessary traffic of products and materials. What is proclaimed as freedom and openness here is meant to abrogate the freedom and openness 'raging' in the city. Not surprisingly, then, the
1 See also Le Corbusier (1943). The Congrès Internationaux d'Architecture Moderne (CIAM) were initiated by Le Corbusier, Gabrie Guévrékian and the art historian Sigfried Giedion (who became the first CIAM General Secretary). The conferences took place in Chateau de la Sarraz, close to Lausanne (Switzerland), between 1928 and 1959, as a Think Tank to address important architectural and town planning issues. 


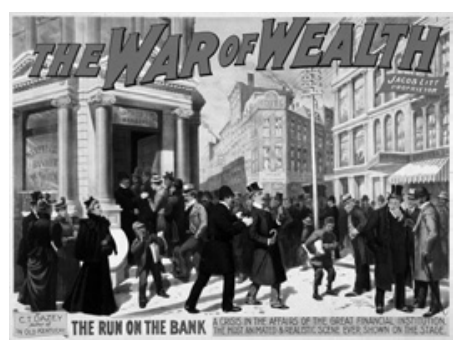

The War of Wealth (Broadway poster). C.T. Dazey, 1895. (Flickr) calm and soothing view from up above, through a plane window on the way from one lecture to the next, becomes the model for planning.

Suppressed behind the drawings of designers like Le Corbusier or Hilbersheimer lies the question of the emergence of the mass - how can intelligent individuals turn into an irrational mass? A mass, according to Tarde and Le Bon, is a creature with altogether different characteristics from its constituent elements. The mass is susceptible to the slightest suggestion or rumour, to superstition, to the venting of spleens, to obsessions, to spectacles. Sociologists and psychologists speak of the madness of crowds. ${ }^{2}$

At the nineteenth-century New York Stock Exchange, a new configuration emerged when European migrant masses, with an orientation towards the future and the unknown, turned themselves into individual speculators. "Curbstone brokers" had capital ranging "from one dollar to ten thousand" (Smith 1868: 47) and they filled "alleys, gutters, and curbstones, making a motley crowd" (48), shouting, yelling and quarrelling. The stock exchange and the streets surrounding it were dominated by the crowd, and represented all that modernist planners would come to fear: impassable sidewalks, a boisterous overflow of commotion. However, the crowd's behaviour was no different from that of the stock brokers inside the Stock Exchange building: "They speak all at once, yelling and screaming like hyenas ... Pandemonium is not wilder, or more disorderly." (46) (Inside, though, it takes only the call "Order! Order!" (47) to hush the chaos in an instant.) This throng becomes the synonym of the market, of speculation. Here lurks the demon of all demons.

Traditionally, this phenomenon was contrasted with the educated audience of the bourgeois public. This was a public to be cultivated and conserved. Attempts were made to draw a clear demarcation between a democratic public and an outside that was incapable of democracy - an outside reduced to its base corporeal materiality. Amongst the public were the propertied classes, while those without property were suspected and demonised as being susceptible to mob mentality. Life in the modern city was to make the existence of the mob unthinkable. Today we know that those included in the public do not suffice for the integration of societies and the maintenance of economies in the bourgeois sense. A certain degree of unleashing has to be allowed: it is not enough that the rich speculate, the common people, too, must buy shares. Investment is imperative: in the countries joining the European Union; in the poor who are persuaded to buy houses on credit; in developing countries who must run into debt. The question is what methods are being used today to neutralise the fear of the masses; how can they be made admissible without becoming irreversibly dangerous; on what basis can trust be established and what role can architecture and town planning play?

The Nazis and Fascists first conceived the total population (as a mass: as suggestible and manipulable) as Volk and placed it under architectural direction. Monumentality, mass ornament and housing estate served as guiding principles for fascist architecture. Today's intellectual reservations towards contained and monumental forms go back to these. But in the modern democracy, too, the bounding limit of the public has to be pushed out further and further, the mass has to be made collectively capable of inclusion. In the drive towards universalisation, the constitutive outside of this distinction must be integrated further and further. However, the once celebrated, critical middle-class itself now threatens to block this expansion. The latest vision is the idea of an all-inclusive democracy as it was sketched out by Walt Whitman: the communitarian masses are the indispensable foundation of democracy; all-embracing affect replaces conflict-ridden democratic
2 Regarding the phenomenon of the Bon, Charles Mackay, Boris Sidis, and Elias Canetti. 
judgement. This affect is to be safeguarded and, at the same time, controlled by participation in the money market (Stäheli 2007).

The Crash has shown us how vulnerable this strategy is, though it could not really call the concept itself into question. Now the question is how the triggers of this contagious and uncontrollable dynamic of the mass are to be minimised within this economic system, while the possibility of their emergence has to be allowed to continue to an ever-increasing extent. Modern society is even especially afraid of those mechanisms because it needs the suggestibility of the masses. Its non-attributable processes rely on blind obedience in order to function. Blind obedience is a social virtue (Stäheli 2007: 197). It is therefore no longer possible simply to contrast order with chaos - one has to acknowledge that the constitution of the social has its own dark underbelly. One order can be converted into another: both belong to the nature of the social, which can no longer be perceived without the mob that lurks under its surface. "Suggestion and suggestibility are therefore not pathological conditions but rather describe basic modes of function within the social.” (Stäheli 2007: 198)

\section{4}

The 'rational' minority of speculating experts and the masses who speculate under suggestion should appear as a unity at the money markets. The all-inclusive ideal of the popular must banish the susceptibility of this imaginary unity to hearsay and panic attacks. At the same time, though, it nurtures the need for a demarcation from the masses (and consequently the distinction between masses and public). Both aspects, the proliferation of players through the admission of the masses and the demarcation of rationality from irrationality, are two sides of the same coin and have to be rebalanced over and over again.

The individual has to be able to act autonomously on his or her own account, and to be suggestible and manipulable at the same time. The weakening of the border between individual and environment that occurs during the formation of masses is to become a permanent condition. Outsiders must be incorporated to become amenable to calls for order. While in some ways extinguishing individual traits in favour of the mass, the stock exchange nevertheless thrives on the confidence of each individual to be better than all the others, an over-confidence in one's own abilities and intuition, and a trust in the mass mentality of others. The shared illusion of limitless wealth serves simultaneously to foster individuation and integration. When this over-confidence collapses and turns into its opposite, panic is contagious. But in panic, too, there is individuation. Further, panic greatly attracts outsiders. "Panic cannot be imagined without observers taking shivering delight." (Stäheli 2007: 223) ${ }^{3}$ Panic's theatricality reinforces aspects of equality while its contagiousness tends to suspend boundaries between the individualist mentality in the bourgeois public and the mob mentality of the masses. Affects, as integral aspects of the social, can be found on the side of the public as much as on that of the masses.

Before the amphitheatre in Verona, Goethe described a self-referentiality that increases and perfects itself in the phenomenon of the spectacular:

... when I wandered about on its highest rim, I had the peculiar feeling that, grand as it was, I was looking at nothing. It ought not be seen

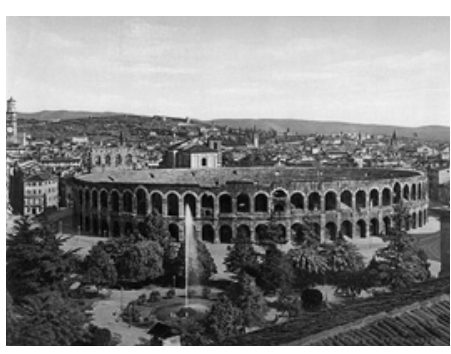

The Arena, Verona, Italy, ca. 1890 ca. 1900. Library of Congress Prints and Photographs Division 
empty but packed with human beings ... Such an amphitheatre, in fact, is properly designed to impress the people with itself, to make them feel at their best." (1970: 52)

For when "crowded together", the people were

... astonished at themselves. They are accustomed at other times to seeing each other running hither and thither in confusion, bustling about without order or discipline. Now this many-headed, many-minded, fickle, blundering monster suddenly sees itself united as one noble assembly, welded into one mass, a single body animated by a single spirit. (52)

This architectural form seems so Daedalian and indispensable to Goethe that he imagines it originating naturally in people's needs and social actions.

When something worth seeing is taking place on level ground and everybody crowds forward to look, those in the rear find various ways of raising themselves to see over the heads of those in front: some stand on benches, some roll up barrels, some bring carts on which they lay planks crosswise, some occupy a neighbouring hill. In this way in no time they form a crater. Should the spectacle be often repeated on the same spot, makeshift stands are put up for those who can pay, and the rest manages as best as they can. To satisfy this universal need is the architect's task. By his art he creates as plain a crater as possible and the public itself supplies its decoration. (52)

The mass enjoys itself.

5

The task assigned to architecture - to concede the emergence of the masses and, at the same time, make them appear to be controlled and dominated - shows modernist conceptions to be insufficient. Architecture must no longer functionally carve up the masses and channel or zone them into parts - the crowd must be allowed to enjoy itself in all its complexity. And this includes its increased suggestibility and vulnerability for spectacles. Modernism promised that the impending chaos on the streets and squares could be met with 'openness' (though any form of openness was split at the cost of complexity into homogenous parts, which were then spatially isolated) and the fear of chaos thereby banished. Today, we demand an architecture capable of bringing together the attractions of enclosed forms, the spectacularity of monumental forms, and the presence of spontaneously populated spaces. This was once propagated in the Renaissance and Baroque. If it were true, as current consensus suggests, that contemporary society differs from Renaissance and Baroque societies by a higher degree of individuation, then (insofar as one understands individuality as autonomy) precisely this socio-psychological assumption should be questioned.

The self-referentiality of the mass, the self-admiration of individuals in speculation, the suggestibility toward special attractions, the over-reliance on flows of imitation, all these might reveal new possibilities when framed by Donald Winnicott's psychoanalytical concept of transitional space $(1953,1967)$. Winnicott observes an original protected space of interaction in the relation between mother and infant, later recurring in the psychoanalytic setting and also, more generally, in everyday situations and relationships. Transitional space is experienced by the infant as a holding relationship; in psychoanalysis it facilitates transference, a 
ceding of control to another who might then provide a support, as the mother did in the early symbiotic constellation, providing through her responses the first cues for self-recognition. As a spatial correlate of such interactions, the city can be conceived as a transitional space in which transference processes take place. In psychoanalysis, previously repressed perceptions of self and affect resurface in fragile and tentative ways and gain greater space; they may fuse in the imagination with the fantasised perfect selfhood of another person. In similar ways, the emotional atmosphere of the city encourages a greater degree of dependence and suggestibility. And precisely this regression to a pre-oedipal, dyadic form of existence might be what is required for the reproductive process of society today. If this is so, then this is what architecture must respond to. So far, this development has not been sufficiently thought through in architectural theory. The cause of this blind spot might just be the misrecognition of the original intentions of the modernist pioneers and their secret anxieties.

If we believe today that we have overcome the errors of modernism in our re-densified cities, we only succumb to new errors. Fear of the regime of the market and the capitalist economy's uncontrollable propensity for crisis was the unconscious of modernist architecture. We can decode modernist architecture as a strategy serving the repression of a narcissistic hurt (formulated by Karl Marx): that, although we make history, we are powerless in the face of our own product. We, too, repress and contemporary architecture, too, is a symptom of the repression of a hurt (helping us to avoid suffering). During modernism, the ideal of the city was the factory, with good light and air and few frictional losses. Today, the whole city is a casino, in which all are invited to participate, and all are registered as participants, but where only a few are winners - just as in Kafka's "Nature Theatre of Oklahoma", the last chapter of his novel Amerika. Architecture is complicit when our increased disposition towards transference makes us succumb to believing in the fallacy of the existence of an all-inclusive society. It helps us avoid awareness that a large part of the population remains in fact excluded - even though there is no rational base for this any longer. And, thus, we can avoid noticing a hurt caused by the recognition of the return of a class-society, based on the deception of the masses.

\section{References}

Benjamin, W. (2005). Franz Kafka: Beim Bau Der Chinesischen Mauer (H. B. Jovanovich, Trans.). In M. W. Jennings (Ed.), Walter Benjamin: Selected Writings 1931-1934 (Vol. 2, pp. 494-499).

Cambridge, Mass.: Belknap Press of Harvard University Press.

Blumenberg, H. (1997). Schiffbruch mit Zuschauer: Paradigma einer Daseinsmetapher. Frankfurt/M.: Suhrkamp.

Ford, E. R. (2003). The Details of Modern Architecture: Volume 2: 1928 to 1988 (Details of Modern Architecture). Boston, Mass.: MIT Press.

Goethe, J. W. (1970). Italian Journey (W. Auden \& E. Mayer, Trans.). London: Penguin.

Le Corbusier (1923). Vers une architecture. Paris: G. Crès \& Cie.

Le Corbusier (1942). Charte d'Athènes. CIAMIV1933. Translated as Le Corbusier (1973), The

Athens Charter. Retrieved from http://modernistarchitecture.wordpress.com/2010/11/03/ ciam\%E2\%80\%99s-\%E2\%80\%9Cthe-athens-charter\%E2\%80\%9D-1933/

Le Corbusier (1943). Urbanisme de CIAM, Charte d'Athènes. Paris: Plon.

Stäheli, U. (2007). Spektakuläre Spekulation. Das Populäre in Der Ökonomie.

Frankfurt/M: Suhrkamp

Winnicott, D. W. (1953). Transitional objects and transitional phenomena-a study of the first notme possession. International Journal of Psycho-Analysis, 34, 89-97.

Winnicott, D. W. (1967). The location of cultural experience. International Journal of Psycho-

Analysis(48), 368-372. 